\title{
Editorial: Climate Impacts on Glaciers and Biosphere in Fuego-Patagonia
}

\author{
Christoph Schneider ${ }^{1 *}$, Matthias Holger Braun ${ }^{2}$, Marius Schaefer ${ }^{3}$, Jussi Grießinger ${ }^{2}$ and \\ Gino Casassa ${ }^{4}$ \\ 'Geography Department, Humboldt-Universität zu Berlin, Berlin, Germany, ${ }^{2}$ Institute of Geography, \\ Friedrich-Alexander-University Erlangen-Nuremberg, Erlangen, Germany, ${ }^{3}$ Institute of Physics and Mathematics, Austral \\ University of Chile, Valdivia, Chile, ${ }^{4}$ Centro de Investigación GAIA Antártica, Universidad de Magallanes, Punta Arenas, Chile
}

Keywords: Patagonia, Tierra del Fuego, cryosphere, biosphere, climate variability, climate change

Editorial on the Research Topic

\section{Climate Impacts on Glaciers and Biosphere in Fuego-Patagonia}

Southernmost South America including Tierra del Fuego and its adjacent islands form the only significant land masses within the mid-latitude Westerlies of the Southern Hemisphere. Since climate variability in the Southern Hemisphere and its impacts are still insufficiently understood, it is essential to improve our understanding of climate impacts and resulting ecological and glacier responses in the region. The Conference and Workshop "Climate Impacts on Glaciers

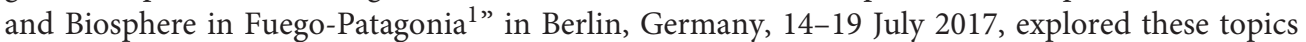
and resulted in the current Frontiers Research Topic. The activities were initiated and linked to the joint research project "Responses of Glaciers, Biosphere and Hydrology to Climate Variability and Climate Change across the Southern Andes" (GABY-VASA) by University of Magallanes and the Instituto Antártico Chileno, both in Punta Arenas, Chile, and the Humboldt-Universität zu Berlin, the Friedrich-Alexander-University Erlangen-Nuremberg and RWTH Aachen University in Germany on dendroclimatology, climatology and glaciology in Southern Patagonia and the Cordillera Darwin, jointly funded by the Chilean Comisión Nacional de Investigación Científica y Tecnológica and the German Federal Ministry of Research and Education.

The regional climate in Southernmost South America is heavily influenced by the proximity to the oceans. This generates rather weak seasonal cycles with cool to cold summers and moderate to cold winters, especially on the western Pacific side. Slightly more pronounced, continental seasonal cycles are observed in the East of the Andes. While annual mean air temperatures across the region are decreasing from North to South precipitation patterns show very pronounced east-west gradients. The distinctive gradients in precipitation are caused by the north-south striking mountain ranges of the Patagonian Andes, and the northwest-southeast stretching mountain chains of the Cordillera Darwin. Both mountain ranges enforce heavy precipitation on the west and southwest exposed flanks by uplift and dry foehn-like conditions on the leesides (e.g., Holmlund and Fuenzalida, 1995; Schneider et al., 2003; Rasmussen et al., 2007) which produces extremely high drying ratios (Escobar et al., 1992; Carrasco et al., 2002; Smith and Evans, 2007). At inter-annual to decadal time scales atmospheric teleconnections such as the El Niño Southern Oscillation (ENSO) (Schneider and Gies, 2004), Southern Annular Mode (SAM), and Pacific Decadal Oscillation (PDO) are influencing spatial and temporal patterns of both, precipitation and air temperature. For example, positive SAM modes (Garreaud, 2009; Weidemann, Sauter, Kilian et al.) and the PDO (Villalba et al., 2003) are associated with higher air temperatures. Langhamer et al. show that the source of precipitation in the Southern Andes also depends on these teleconnections.

\footnotetext{
${ }^{1}$ https://www.geographie.hu-berlin.de/en/professorships/climate_geography/patagonia_workshop
} 
An important aspect is that Patagonia and Tierra del Fuego, together with the sub-Antarctic islands are the only regions where direct proximity between Antarctica and land masses north of the Southern Ocean is given. Such linkages are for example explored with investigations by Hebel et al. on the biosphere and Oppedal et al. for the regional glacier history.

The Humboldt or Peru Current transports cold waters along the Pacific coast of South America and the strong Westerlies cause reduced air temperatures combined with heavy precipitation in Southern South America. This setting induces both, unique eco-systems comprised by extensive bogs, evergreen and broadleaf Nothofagus (rain) forests, as well as characteristical elements of the cryosphere including extensive seasonal snow cover (Aguirre et al.). The mountain ranges host major ice bodies such as the Northern and Southern Patagonia Icefields and the Icefield of the Cordillera Darwin all of them with outlet glaciers reaching down as far as sea level. In addition, a multitude of smaller ice caps and glaciers are wide-spread.

On the eastern side of the Andes, the small ocean basins along the Strait of Magallan, the glacially formed gulfs of Seno Skyring and Seno Otway and large glacial lakes such as Lago Argentino and Lago Viedma provide evidence of extended glaciation until the Last Glacial Maximum (e.g., Rabassa et al., 2011). In recent centuries glacier re-advances cumulated in Little Ice Age maximum glacier extents and associated trimlines and moraines mostly dating from the second half of the nineteenth century as for example explored in Meier et al.. The underlying changes in climate can be evidenced by analyzing dendroclimatological records as pinpointed for example for $N$. pumilio in this Research Topic by Srur et al. and Grießinger et al..

Due to the temperate nature of glaciers associated with its high mass turnover, ice bodies in Patagonia and Tierra del Fuego tend to respond quickly and highly sensitive to atmospheric forcing as shown by analyzing the energy and climatic mass

\section{REFERENCES}

Aristarain, A., and Delmas, R. (1993). Firn-core study from the Southern Patagonia Ice Cap, South America. J. Glaciol. 39, 249-254. doi: 10.1017/S0022143000015914

Braun, M. H., Malz, P., Sommer, C., Farías-Barahona, D., Sauter, T., Casassa, G., Soruco, A., et al. (2019). Constraining glacier elevation and mass changes in South America. Nat. Clim. Change 9, 130-136. doi: 10.1038/s41558-018-0375-7

Carrasco, J., Casassa, G., and Rivera, A. (2002). "Meteorological and climatological aspects of the Southern Patagonia Icefield," The Patagonian Icefields. A Unique Natural Laboratory for Environmental and Climate Change Studies. Series of the Centro De Estudios Científicos, eds G. Casassa, F. V. Sepúlveda, and R. M. Sinclair (Boston, MA: Springer), 29-41. doi: 10.1007/978-1-4615-0645-4_4

Escobar, F., Vidal, F., Garin, C., and Naruse, R. (1992). "Water balance in the Patagonia Icefield," Glaciological Researches in Patagonia 1990, eds R. Naruse and M. Anyia (Nagoya: Japanese Society of Snow and Ice), 109-119.

Garreaud, R. D. (2009): The Andes climate and weather. Adv. Geosci. 7, 1-9. doi: 10.5194/adgeo-22-3-2009

Holmlund, P., and Fuenzalida, H. (1995). Anomalous glacier responses to 20th century climatic changes in the Darwin Cordillera, Southern Chile. J. Glaciol. 41, 465-473. doi: 10.1017/S0022143000034808

Lenaerts, J. T. M., van den Broeke, M. R., van Wessem, J. M., van de Berg, W. J., van Meijgaard, E., van Ulft Lambertus, H., et al. (2014). balance in details in Weidemann, Sauter, Malz et al.. There is overall consensus that anthropogenically induced global climate warming has a major impact on the cryosphere in FuegoPatagonia. Nonetheless, it is still under debate how precisely recent glacier retreat and glacier thinning (e.g., Braun et al., 2019; Dussaillant et al.) can be explained by the combination of recent climate warming and glacier adjustment to late nineteenth century to twentieth century climate variability. Since there are no direct measurements on the icefields, accumulation can only be deduced from firn cores and numerical modeling providing a wide range of 7-34 m per year (Aristarain and Delmas, 1993; Shiraiwa et al., 2002; Schwikowski et al., 2013; Lenaerts et al., 2014; Schaefer et al., 2015). It is disputable if-despite the high drying ratios-such high accumulation rates are feasible by atmospheric moisture transport. An effort toward solving this issue is undertaken by Langhamer et al. by analyzing sources of precipitation.

\section{AUTHOR CONTRIBUTIONS}

CS drafted the editorial. MB, JG, MS, and GC subsequently contributed to the text of the editorial. This contents of the editorial was jointly discussed by all authors.

\section{FUNDING}

The workshop on Climate Impacts on Glaciers and Biosphere in Fuego-Patagonia on which this Research Topic builds was funded by the CONICYT-BMBF project GABY-VASA under Grant Nos. 01DN15007 and 01DN15020. Further support for the workshop by Geo.X, the Research Network for Geosciences in Berlin and Potsdam, Germany and the Embassy of Chile in Berlin, Germany are gladly acknowledged.
Extreme precipitation and climate gradients in Patagonia revealed by highresolution regional atmospheric climate modeling. J. Clim. 27, 4607-4621. doi: 10.1175/JCLI-D-13-00579.1

Rabassa, J., Coronato, A., and Martínez, O. (2011). Late Cenozoic glaciations in Patagonia and Tierra delFuego: an updated review. Biol. J. Linnean Soc. 103, 316-335. doi: 10.1111/j.1095-8312.2011.01681.x

Rasmussen, L., Conway, H., and Raymond, C. (2007). Influence of upper air conditions on the Patagonia icefields. Glob. Planetary Change 59, 203-216. doi: 10.1016/j.gloplacha.2006.11.025

Schaefer, M., Machguth, H., Falvey, M., Casassa, G., and Rignot, E. (2015). Quantifying mass balance processes on the Southern Patagonia Icefield. Cryosphere 9, 25-35. doi: 10.5194/tc-9-25-2015

Schneider, C., and Gies, D. (2004). Effects of El Niño-southern oscillation on southernmost South America precipitation at $53^{\circ} \mathrm{S}$ revealed from NCEPNCAR reanalysis and weather station data. Int. J. Clim. 24, 1057-1076. doi: 10.1002/joc.1057

Schneider, C., Glaser, M., Kilian, R., Santana, A., Butorovic, N., and Casassa, G. (2003). Weather observations across the Southern Andes at $53^{\circ}$ S. Phys. Geogr. 24, 97-119. doi: 10.2747/0272-3646.24.2.97

Schwikowski, M., Schläppi, M., Santibañez, P., Rivera, A., and Casassa, G. (2013). Net accumulation rates derived from ice core stable isotope records of Pío XI glacier, Southern Patagonia Icefield. Cryosphere 7, 1635-1644. doi: 10.5194/tc-7-1635-2013 
Shiraiwa, T., Kohshima, S., Uemura, R., Yoshida, N., Matoba, S., Uetake, J., and Godoi, M. (2002). High net accumulation rates at Campo de Hielo Patagonico Sur, South America, revealed by analysis of a $45.97 \mathrm{~m}$ long ice core. Ann. Glaciol. 35, 84-90. doi: 10.3189/172756402781816942

Smith, R. B., and Evans, J. P. (2007). Orographic precipitation and water vapor fractionation over the southern Andes. J. Hydrometeor. 8, 3-19. doi: $10.1175 / J H M 555.1$

Villalba, R., Lara, A., Boninsegna, J. A., Masiokas, M., Delgado, S., Aravena, J. C., et al. (2003). Large-scale temperature changes across the southern Andes: 20 th-century variations in the context of the past 400 years. Clim. Change 59, 177-232. doi: 10.1023/A:1024452701153
Conflict of Interest: The authors declare that the research was conducted in the absence of any commercial or financial relationships that could be construed as a potential conflict of interest.

Copyright $\odot 2020$ Schneider, Braun, Schaefer, Grießinger and Casassa. This is an open-access article distributed under the terms of the Creative Commons Attribution License (CC BY). The use, distribution or reproduction in other forums is permitted, provided the original author(s) and the copyright owner(s) are credited and that the original publication in this journal is cited, in accordance with accepted academic practice. No use, distribution or reproduction is permitted which does not comply with these terms. 